\title{
中小河川群の汇濫解析と気象情報を利用した 地域防災計画が想定する災害イメージの事前構築
}

\author{
竹之内健介 1 -中島秀明 2 - 田中耕司 3 - 中北英一 4 - 矢守克也 $5 \cdot$ \\ 養老伸介 $6 \cdot$ 羽生雅則 6 \\ 1 正会員 工修 京都大学 情報学研究科（广606-8501 京都市左京区吉田本町 36-1） \\ E-mail:k.takenouchi@drs.dpri.kyoto-u.ac.jp \\ 2 正会員 工修（株）建設技術研究所 大阪本社水システム部（テ545-0005 大阪市中央区道修町 1-6-7） \\ 3 正会員 工博 （株）建設技術研究所 大阪本社水システム部（テ545-0005 大阪市中央区道修町 1-6-7) \\ 4 正会員 工博 京都大学防災研究所教授 気象・水象災害研究部門（T611-0011 京都府宇治市五ヶ庄） \\ 5 非会員 人博 京都大学防災研究所教授 巨大㷋害研究センター（可611-0011 京都府宇治市五ヶ庄） \\ 6 非会員＼cjkstart福井県大野市＼cjkstart防災防犯課（广912-8666 福井県大野市天神町 1 番 1 号）
}

中小河川群周辺における洪水や浸水のリスクは, 河川だけでなく水路や地域性などの複合的な要因を評 価する必要があるため, その判断と予測が難しいのが現状である.

本研究では, 高解像内外水汇濫解析モデルを利用し, 詳細な浸水リスクを確認した上で, その情報を地 域性の高い身近な情報として利用することの可能性を確認するとともに，気象情報との関係性について評 価した。実際に福井県大野市において地域防災計画が想定する災害の一つである1965年の奥越豪雨の降水 パターンを事例にその評価を行った。

またこの汇濫解析の結果を, 身近な災害情報として利用し, 災害のイメージを事前に住民間において構 築することの効果について, 大野市立有終西小学校で実施した実践型防災教育における児童達の災害イメ ージ調査から評価を行い, その有効性を確認した。

Key Words : locality, weather information, flood flow analysis, local disaster management plan, disaster education

\section{1. 中小河川群における災害へのアプローチ}

（1） 中小河川群における内外水氾濫への災害対応とその 課題

洪水時の避難のタイミング・方法を定める場合には, 河川・水路群からの複合的な汇濫に基づく浸水情報を考 慮することが望ましい，しかし，中小河川ではその情報 収集が困難であるとともに，十分な情報が住民に伝わら ない可能性もある. そのため, 別の方法で迫り来る危機 に気づき, 判断し, 対応を開始寸ることが必要となる. 実際，指定河川洪水予報は主に大規模河川を対象として おり ${ }^{1)}$ ，洪水注意報・警報も対象区域のいくつかの河川 について流域雨量指数や時間雨量などを利用して洪水の 危険度を評価している2．それ以外の中小河川について は基本的にはこれらの情報から評価することとなり，特

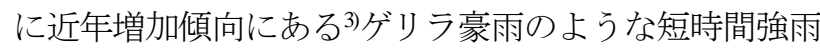
により発生しうる被害（平成23年宇治市)など）に見ら れるような中小河川の汇濫については，予測も含め，行
政の危険周知も難しいのが実情である，そのため，行政 の対応を待つのではなく, 住民自身が災害の予兆を感じ 取り対応する必要がある. なお, 内水汇濫については, 大雨注意報・警報により災害の危険が呼びかけられてい るが，河川の増水に伴う排水不良等に伴う内水汇濫につ いては, 複合的な評価が別途必要となるため, 詳細な堤 内地における中小河川群・水路等の計算が必要となり, 評価は十分とは言えない。

\section{(2) 高解像内外水汇濫解析モデル}

汇濫濫解析モデルとしては数多くのものが開発されて いるが，前節のような課題に対応するには，従来の外水 氾濫だけではなく, 内水汇濫に関係する地域の詳細な情 報を考慮する必要がある. 実際に, 空間解像度の高い氾 濫解解析による地域の災害リスクの把握を行っている事 例もある. 瀧ら ゆ，広域的な汇濫原を $50 \mathrm{~m}$ メシンと いう解像度で解析し, 自治会単位での汇濫リスクを, 内 外水汇濫を同時に扱える統合水理型モデルを用いて分析 を行った，また，著者の一人である田中ら けは，同様の 
モデルを利用し，想定された内外水汇濫現象と過去の災 害教訓から住民の自主的な避難につながる情報の作成を 試みている。これらの事例は，空間解像度の高いモデル を利用し，地域の中小河川群の氾濫リスクを評価するた めに利用した事例であるが，まだ事例としては少ない.

\section{（3）災害情報における課題と地域性の高い情報}

冒頭で挙げた各種災害情報については以前から過度な 情報依存状態 わや，ダブル・バインドによる災害時の対 応不全が指摘されている ${ }^{8)}$. 短時間に対応が必要となる ような中小河川に関連する災害においては，災害対応の 遅れが致命的になる可能性があるため, 情報の利活用だ けでなく，事前の想定災害リスクなどを利活用した災害 に対する意識啓発が重要と言える.

一方で，災害情報については，よりわかりやすい表現 や身近な地域独自の表現を利用寸ることによる危険意識 の改善効果が指摘されている9.このような表現による 改善効果を利用し, 気象情報の利用者と作成者が気象情 報を共同構築し，その災害リスクに対する意識の融合を 図る地域気象情報 ${ }^{10)}$ の研究を著者の一人は試みている. 地域気象情報は，関係者間で共同構築する気象情報であ ると同時に，現在の気象情報を住民にとって身近でわか りやすい地域性の高い情報に結び付けて利用することを 目指しており，地域防災計画における想定災害リスクを 既存の気象情報と関連付けて，身近な地域気象情報とし て住民に伝えることは，想定災害リスクの有効な意識啓 発になりうる.

\section{2. 内外水汇濫解析モデルと地域気象情報の連携}

\section{（1）地域気象情報を活用した住民目線での避難判断}

本研究は，福井県大野市を事例として，大野市地域防 災計画における行政の避難勧告等の発令基準の策定や住 民の自主的な避難を支援することを目的として実施して いる.

その中で，中小河川群の周囲に居住する住民の適切な 災害時の対応行動を支援するために，高解像内外水汇濫 解析モデルの解析結果から地区毎の浸水リスクを評価し， さらに浸水リスクと現行の気象情報の関係性を確認する とともに，地域にとって身近なリスク情報である地域気 象情報として利用寸ることを検討している．特に，中小 河川群等の地域性の影響を大きく受ける災害については, 地域気象情報との親和性が高いと考える.

\section{（2）内外水汇濫解析モデルと地域気象情報が連携する意 味}

通常，地域防災計画においては，避難情報の判断基準 の一つとして, 河川水位などの情報が利用される. 本研 究における汇濫解析モデルのように，汇濫解析モデルに

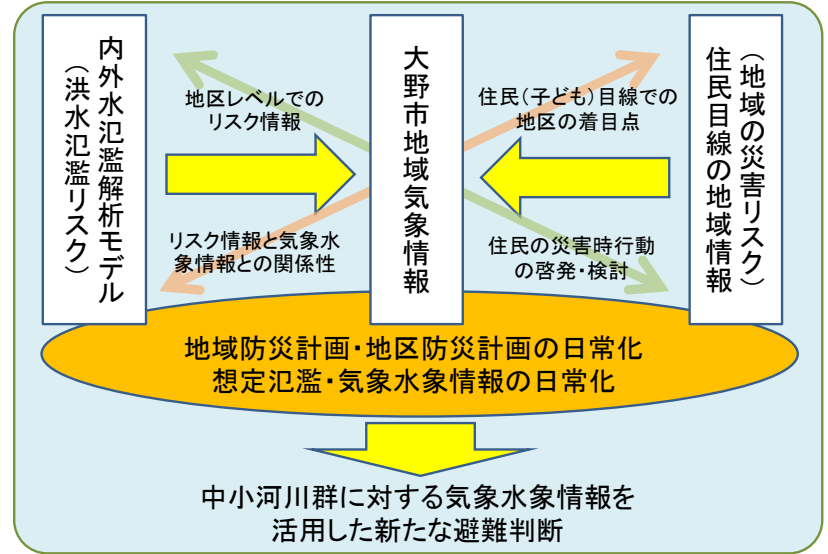

図-1 内外水汇濫解析モデルと地域気象情報の連携.

より河川の想定氾濫を確認し，それを条件として利用す る場合も多い，しかし，そのような汇濫解析の結果は， 自治体の避難判断基準の参考として利用されるものの, その中身は住民に十分に知られておらず，自治体が伝え る災害リスクが住民に浸透していない場合が多い．

本研究では，内外水汇濫解析モデルと住民の両者を地 域気象情報の概念を利用寸ることで結び付け，解析結果 を住民目線で捉え，災害イメージを事前に構築しておく ことにより，地域住民の災害リスクの認識を高めること を意図している。逆に解析結果を地域性の高い情報とし て利用することで, 内外水汇濫解析モデルからの情報を 専門家しか理解できないようなものでなく，地域住民に も理解できるものとすることで，汇濫解析モデルが果た すべき防災・減災の効果が高められる（図-1）。

このことは，地域住民にとっては馴染みの薄い地域防 災計画における避難情報を，身近な地域気象情報として 日常的に理解しておくことで，災害時に避難情報がごの 程度の危険を知らせ，自身はどのように行動すべきかを 理解する助けとなる。 また，昨今策定が進められている

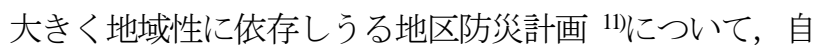
然科学の視点から支援するとともに，その計画を地域で 実践できる具体的なものにする意味でも重要と言える.

そして，このように災害リスクの認識を高めることは 適切な災害リスクの理解を進め, 前章でも触れた災害情 報に対する過度な情報待ちの改善につながりうるととも に，地域気象情報を利用し地域防災計画や地区防災計画 の日常化を進めることで，地域住民と災害情報とのリス クコミュニケーションの活性化が期待される.

本研究では, 対象地域の概要や汇濫解析モデルについ て 3 章で確認し，4 章でそのモデル結果を地域気象情報 として利用する可能性を検討した. そして 5 章において, 実際に身近な地域気象情報として利用することの効果を， このモデル結果を利用して実施した大野市立有終西小学 校における実践型防災教育の成果から確認寸る.

\section{3. 高解像内外水汇濫解析モデル〜福井県大野市}




\section{を事例に〜}

\section{(1) 大野市市街地の概要}

本論で対象とする大野市の市街地の概要を図-2 に示 す. 名水百選に選ばれる御清水に代表されるように市街 地内に細かな水路が張り巡らされた水の街である 12). 市 街地を赤根川，清滝川，真名川などが流れ，それぞれ九 頭竜川に流入している. 現在，九頭竜川は指定河川洪水 予報の対象であり，赤根川も洪水注意報・警報の評価対 象となっているが，それ以外の河川については，現在の 洪水情報の枠組みでは明確な評価がないのが実情である。 なお，これらの河川は，過去に何度か汇濫を経験してい る（昭和 40 年奥越豪雨 ${ }^{13)}$ ，平成 16 年福井豪雨 ${ }^{14) な と ゙ ） 。 ~}$

\section{(2) モデル概要}

大野市内については過去の浸水実績より，河川からの 氾濫（越水・堤防の破堤）のみならず内水汇濫も考慮す ることが必要である，実際には，対象となる河川が汇濫 する前に，農業排水路，普通河川や小規模な一級河川な どの汇濫が先に生じることも想定される．このような現 象を表現するため, 内外水汇濫解析モデルを構築した. 構築にあたり，河道内の水理モデル，堤内地の汇濫流の 水理モデルおよび雨水管線（水路）の水理モデルを組み 合わせたモデルとした. 河道モデルとして, Dynamics wave モデルを適用するとともに，河道網は一次元不定流 計算を適用し，有堤部における越水や破堤は堤防高以上 の水位で汇濫（越水・溢水）が生じる現象と順次破堤を 追跡できる平面 2 次元氾濫水理モデルを適用した. 汇濫 解析手法の概要は表-1 のとおりである。また汇濫解析

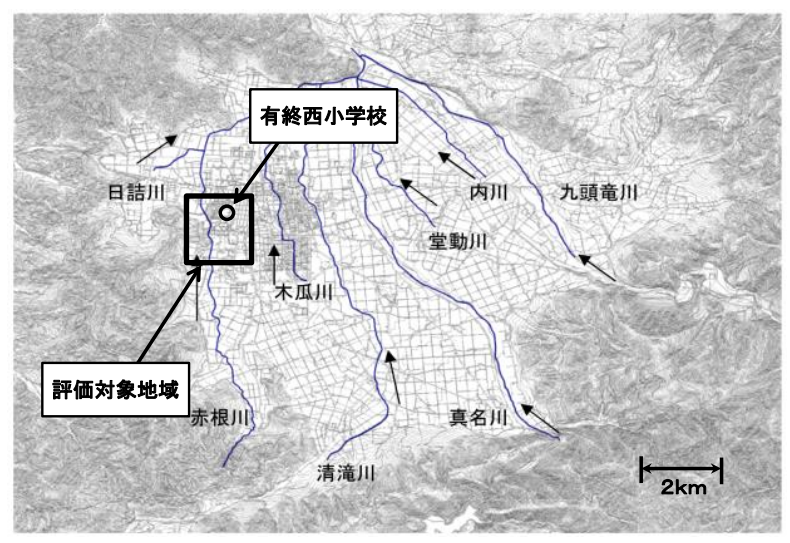

図-2 大野市内中小河川群及び本研究における評価対象地域
の各種条件は表-2のとおりである.

(3) 解析事例

本研究における汇濫解析事例の降水パターンとして, 中央集中型波形や一定降水型波形，過去事例型を含め, 複数の降水パターンについて複数期間の確率規模降水量 について，評価を行った（各降水パターンの詳細やその 解析結果については中島ら 15)を参照いただきたい)。本 論文では，そのうち過去事例型として死者行方不明者 11 名という ${ }^{11}$ 地域に甚大な被害をもたらした昭和 40 年 9 月の奥越豪雨を対象として分析を行った．奥越豪雨当時 の大野観測所における降水分布を図-3 に示す。なお, 当時はレーダーデータ等の空間解像度の高い観測データ がないことから，このような行政機関管理の雨量観測所 の雨量值を基に，対象範囲周辺の複数の観測所から距離 に応じた加重平均で算出した雨量をメッシュ毎に設定し た. この雨量に基づく, 有終西小学校周辺における内外 水汇濫解析モデルによる浸水予測結果を図-4 に示す. この結果から, 有終西小学校の南に位置する地域（泉 町）において，深いところで，1.0-2.0m の浸水が確認さ れた。

このように高解像内外水氾濫モデルを利用することに より，想定降水条件の下，中小河川群・水路の詳細な状 況把握が可能であり，様々な豪雨に対して，事前に地域 の浸水リスクを住民が理解することが可能である.

\section{4. モデル結果と各情報の関係性}

\section{（1） モデル結果から得られる避難判断の指標となる地域 性の高い情報}

前章では内外水汇濫解析モデルを利用し，地域の詳細 な浸水状況を確認した。本解析の解像度は $25 \mathrm{~m}$ であるた め，地域住民にとってより身近な場所の状況を理解する ことが可能である，そこで，前章の解析結果を下に，地 域の浸水リスクを地域住民の視点から確認していく.

表-1 汇濫解析手法.

\begin{tabular}{|c|c|}
\hline 項目 & \multicolumn{1}{|c|}{ 内容 } \\
\hline 河道 & 一次元不定流モデル (Dynamics wave) \\
\hline 氾濫原 & 二次元不定流モデル (Dynamics wave) \\
\hline 排水路モデル & 一次元不定流モデル (Diffusion wave) \\
\hline
\end{tabular}

表-2 汇濫解析条件.

\begin{tabular}{|c|c|}
\hline 項目 & 内容 \\
\hline 設定降雨 & 実績降雨 : 奥越豪雨 \\
\hline 河道設定 & 九頭竜川，真名川，清滝川，赤根川，木瓜川，日詰川を河道として設定 \\
\hline 地盤高 & 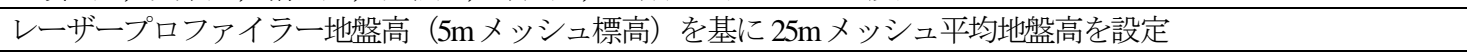 \\
\hline 粗度係数 & $\begin{array}{l}\text { 宅地以外（農地 }(0.060) \text {, 道路 }(0.047) \text {, その他 }(0.050) \text { の粗度と, 国土基盤地図情報に含まれている建物の外形データよ } \\
\text { り算定した建物占有率を使った合成粗度 }\end{array}$ \\
\hline 排水路 & 大野市排水路計画と現地調査を基に,水路網および諸元を設定 \\
\hline 構造物 & $\begin{array}{l}\text { 道路, 鉄道, 支川堤防等の盛土構造物を基礎情報とし, LP データを活用した比較検討により, 盛土構造物の位置 } \\
\text { および諸をを設定 }\end{array}$ \\
\hline
\end{tabular}




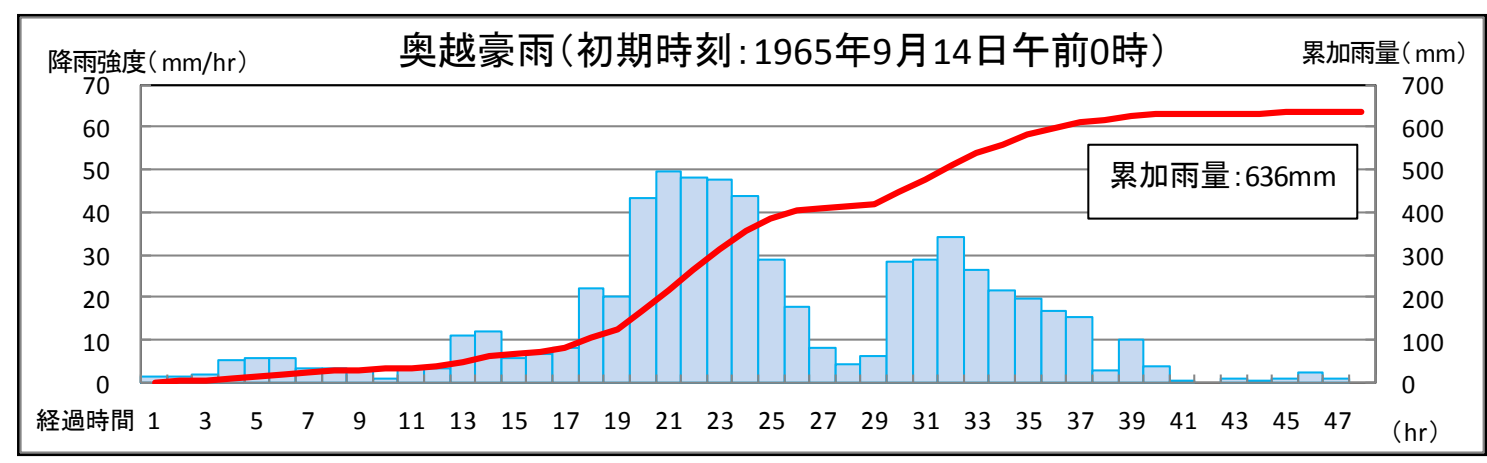

図-3 昭和 40 年奥越豪雨当時の大野観測所における降水分布.
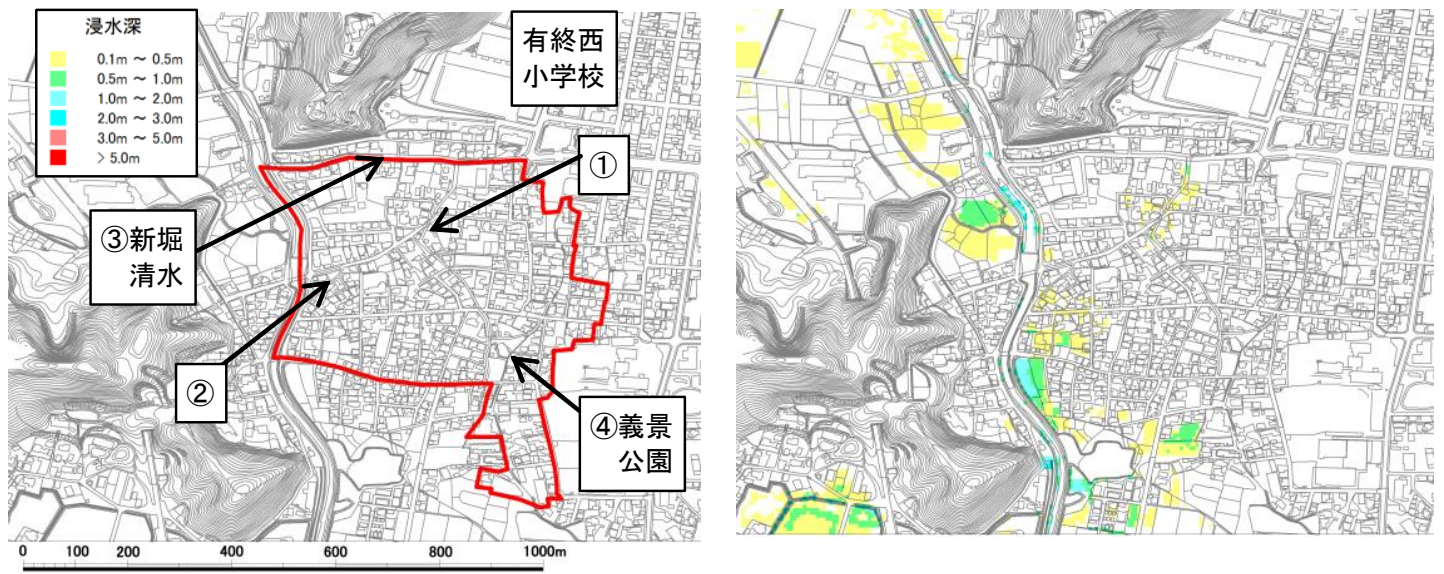

地域概要図

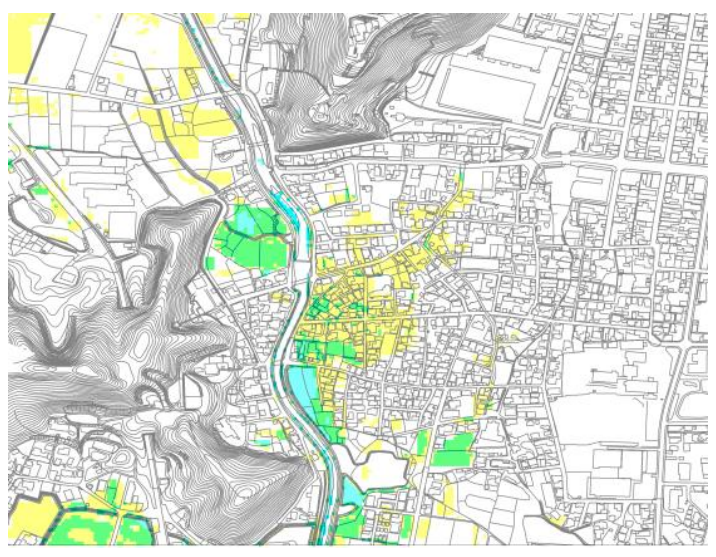

$\mathrm{FT}=20$

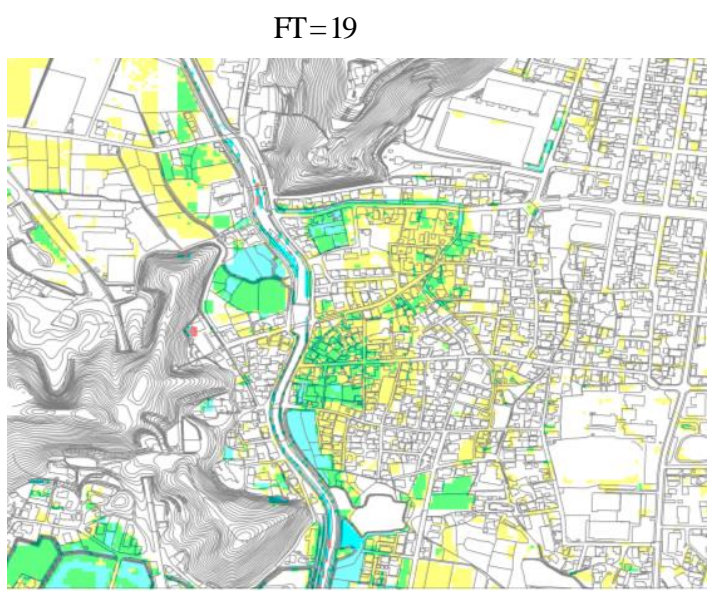

$\mathrm{FT}=21 \quad$ (FT : 初期時刻からの経過時間 $)$

図-4 奥越豪雨型降水分布に基づく内外水汇濫モデルによるその浸水予測結果（泉町周辺地域 : 左上図赤線内）.

\section{a) 第1段階 : 道路の冠水 · 床下浸水}

図-4に示した泉町内の各地点の浸水想定イメージを図 -5に示寸．また図-6に泉町における浸水状況とこのとき 想定される気象情報や隣接する赤根川の水位情報を時系 列としてそれぞれ示す．泉町内でまず浸水する地域は地 点(1)である． FT=18.5（以下，FTは図-3における経過時 間と同じものを意味する。）の時点でこの地域は水路か らの越水及び床下浸水が確認される．そのため，初期段 階として，地域住民にもわかる地点(1)の水路の越水の危 険を情報として知らせることが有効と言える.

\section{b) 第2段階 : 家屋の床上浸水}

次の段階として, $\mathrm{FT}=19.0$ の時点で，泉町内地点(2) おいて浸水し始め，一部床上浸水となる.

\section{c) 第3段階 : 歩行困難エリアの発生}

第3段階として，地域に歩行困難エリアが発生し始め る. 本事例では, 泉町の他地域との行き来に重要な幹線 道路である地点(2)の箇所が歩行困難になることが予想さ れ，周辺の浸水により見えなくなった水路等に流される 危険が生じる．また地点(3)や地点(4)など地域住民がよく 知る箇所も浸水し始めることから，これらの地点を第3 段階の災害リスクの指標として捉え，地域の災害状況を 伝えることで，被害を抑制しうる.

このように各段階に応じた地域住民にとって身近な地 点の状況を, 災害リスク情報として, 地域で共有するこ とで, 災害リスクの適切な把握につなげることが可能と なる. 

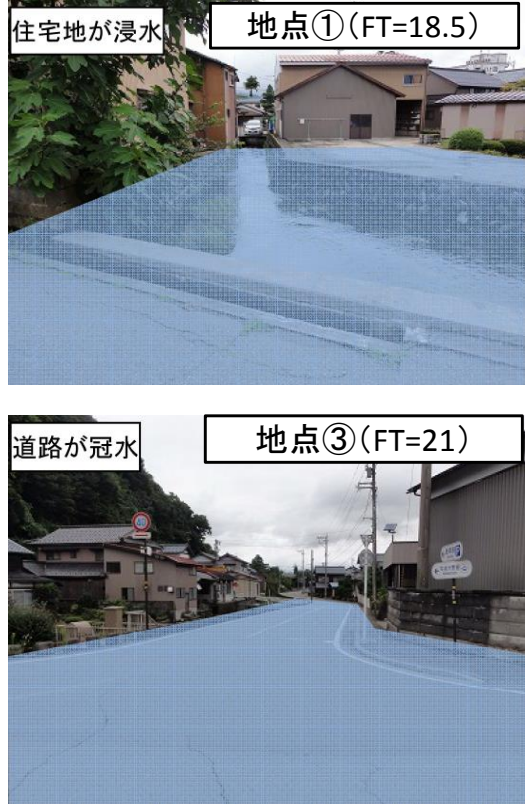

図-5＼cjkstart奥越豪雨型降水時の内外水氾濫モデルによる泉町内の想定浸水状況. (FT : 初期時刻からの経過時間)

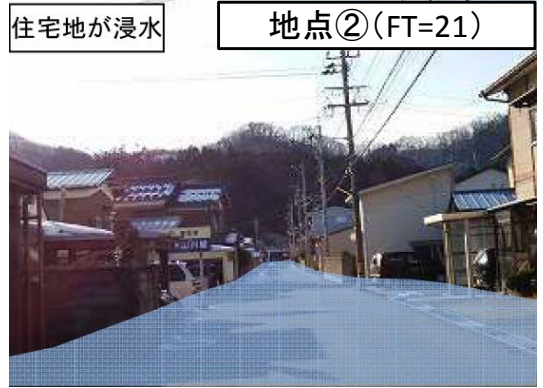

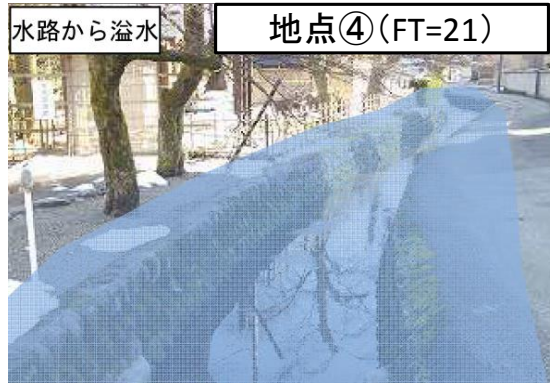

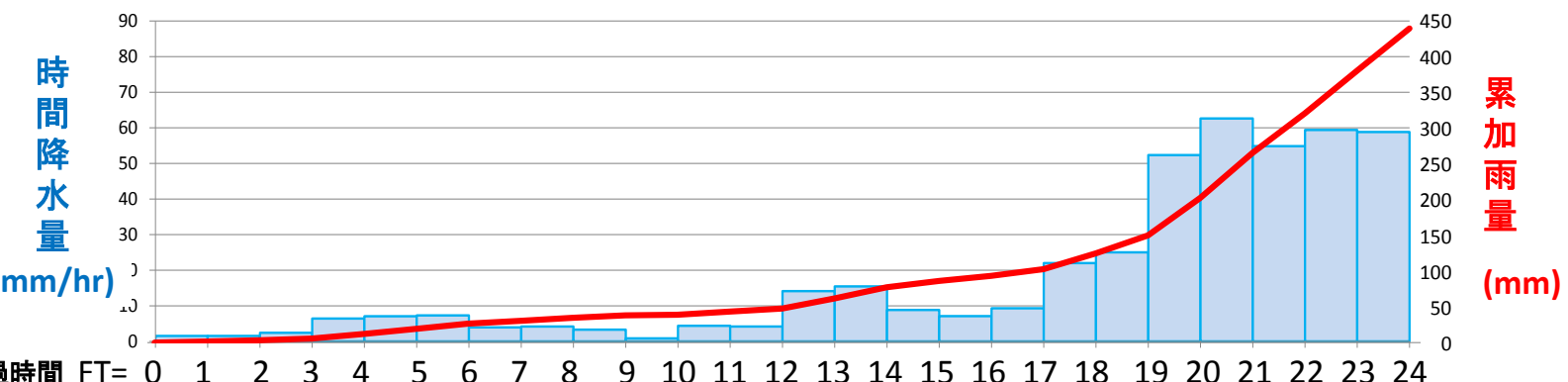

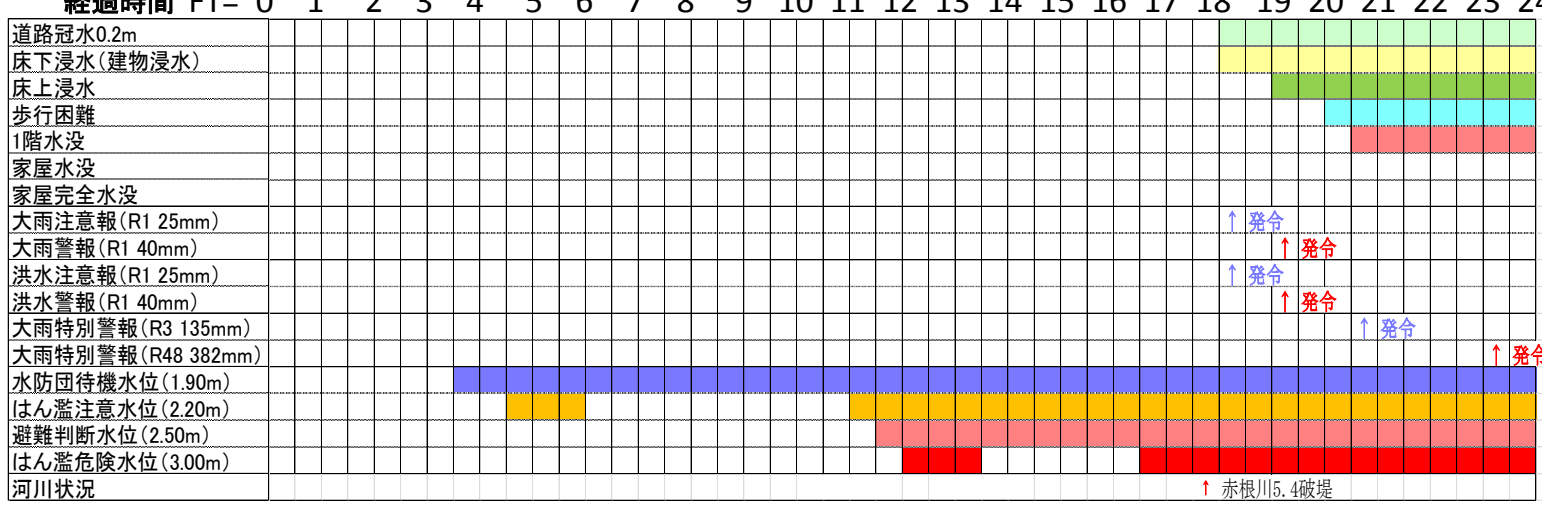

図-6＼cjkstart奥越豪雨型降水時の泉町における浸水予測と想定される気象情報，河川情報等の時系列変化.

\section{（2）モデル結果に基づく地域情報と気象情報等の関係}

前節では，解析結果から地域の状況を確認した. 次に, そのような地域の状況と気象情報や河川情報との関係性 を確認する。

図-6には地域の状況と併せて，想定される気象情報 や河川情報の該当状況が示してある．なお，各情報は， 平成 26 年 3 月 1 日時点での基準を採用し, 大雨や洪水 の気象情報については基準項目のうち雨量基準を評価対 象とし，赤根川の水位情報については，大橋観測所を基 準とした．また大雨特別警報についても，雨量基準のみ を評価し基淮該当格子数は省略しているため，実際の発 令基準とは異なり，目安として示している.
図-6 から，まず泉町が被災し始める前段階として赤 根川が汇濫危険水位を超過する。この段階では泉町への 被害はない。しかし，その後大雨注意報基準を超える降 水に到達すると地域内で道路冠水と床下浸水が始まる. さらに大雨警報基準を超えると床上浸水する世帯が発生 する. そして，3 時間降水量が大雨特別警報基準に到達 した段階では歩行困難と 1 階水没が確認される.

このように，本事例では，大雨注意報・警報・特別警 報について，それぞれの基準雨量と泉町の被害レベルと の対応がよい結果となった。このことは，例えば，赤根 川の氾濫危険水位超過の見込みと大雨警報の発表が予想 される場合に，単に「赤根川が汇濫危険水位を越え，大 
雨警報が発表されました.」と既存の気象情報や河川情 報を伝えるのでなく，具体的に泉町内での床上浸水の可 能性を知らせることで，地域住民に今後の地域の状況を 事前に伝えることが可能と言える.

また大雨特別警報については，重大な災害が起こるお それが著しく大きい状況下で，災害が起きているもしく はいつ起きてもおかしくない場合に発表される情報であ り，実際に図-6において泉町内で歩行困難区域や 1 階水 没が発生している.このことは，地域の被害が段階的に 進んでいくことを考慮すると，第 2 段階の床上浸水の段 階で, 次の大雨特別警報に相応寸る地域の災害を予見し た災害対応の検討が可能であることを意味している．つ まり，地域の情報と気象情報を結び付けて理解しておく ことにより，地域の状況や気象情報から，その後の地域 の状況を連想させ，事前に災害時の対応行動を励起させ る効果をもたらし得る.

\section{（3）地域気象情報と高解像内外水汇濫解析モデルの結合}

本事例の泉町内における浸水は，赤根川が増水してい る状況下で，多量の降水により，地域において排水不良 が発生，地域の浸水に至った事例である。このことは, 上述の結果からもわかるように，赤根川の水位と地域の 降水量から，地域の被害予想がある程度可能であること を示している. つまり, 赤根川大橋観測所における水位 状況と, レーダー情報や大雨警報などの地域での降水量 の予想を利用することで，これらの情報を事前に地域住 民にとって身近な災害情報に変換して利用することが可 能である. さらに図-6 からわかるように第 1 節の第 1 段 階から第 3 段階まで 2 時間の余裕があることを加味する と，まずは地域の道路冠水を指標として，次の地域の危 険を事前に共有することで事前の災害対応への活用も可 能である.

ここでは奥越豪雨の降水パターンを事例に議論を展開 してきたが，実際には，降水規模のパターンを複数確認

表-3 有終西小学校における実践型防災教育の実施内容

\begin{tabular}{|c|c|l|}
\hline & 実施日 & \multicolumn{1}{|c|}{ 内容 } \\
\hline 第1回 & 2014.4 .25 & $\begin{array}{l}\text { 学校周辺における浸水リスクの勉 } \\
\text { 強と現地確認 }\end{array}$ \\
\hline 第2回 & 2014.5 .15 & 地域の浸水リスクマップ作成 \\
\hline 第3回 & 2014.5 .21 & $\begin{array}{l}\text { 地域防災計画の意味と水害時の対 } \\
\text { 忘 (クロスロード) }\end{array}$ \\
\hline 第4回 & 2014.6 .4 & $\begin{array}{l}\text { 児童による地域の浸水リスクマッ } \\
\text { プの保護者や住民への発表会 }\end{array}$ \\
\hline
\end{tabular}
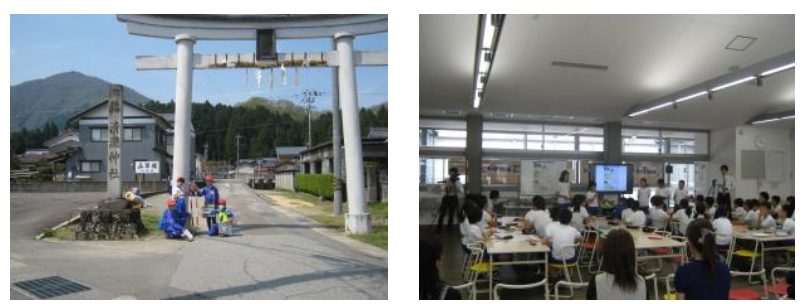

図-7 大野市立有終西小学校における授業の様子
し，より詳細な評価が必要である.しかし，このように 高解像内外水汇濫解析モデルを利用し，その結果と気象 情報を結び付けることにより，これらの情報を身近な地 域気象情報として利用し，地域の災害へのイメージを高 めることにつなげることが可能と言える．またこのこと は，地域防災計画がどのような災害を想定し，どのよう な役割を果たしうるか広く住民に伝えることにもつなが ると言える.

\section{5. 汇濫解析の結果を利用した実践型防災教育}

\section{（1）有終西小学校における実践型防災教育}

地域防災計画の啓発のため, 大野市立有終西小学校に おいて 2014年 4月から 6月の期間にかけて，小学 5年生 39 名を対象に計 4 回の防災教育を実施した。本防災教育 では, 実際に前章で取り上げた高解像度の汇濫解析の結 果である地域防災計画における事前災害想定を利用し， 地域性の高い災害情報を地域に身近な情報として览童の 目線で捉えることにより, どのような防災教育の効果と 災害に対する意識の変化が生まれるかを確認した。なお， 住民を対象でなく児童を対象としているのは，当初の計 画として子ども達に対する防災教育の実施とそこから地 域住民への意識変化の派生を考慮しているからである.

本実践型防災教育における授業内容の概要を表-3に, 授業時の様子を図-7 に，成果として作成した地域の浸 水リスクマップ（通称：子ども地域防災計画）の一例を 図-8にそれぞれ示寸，授業においては，児童たち自身 が浸水想定を現地で確認し，そこから身近な指標物と一 緒に写真を撮るなどしながら，地域の防災マップを作成 することを通して, 汇濫解析の結果を肾童でもわかる地 域の情報として整理できるようにした．また，これが単 なる学習ではなく, 学区内で実際に発生しうる地域防災 計画が想定する自分達の災害リスクである点を説明した。

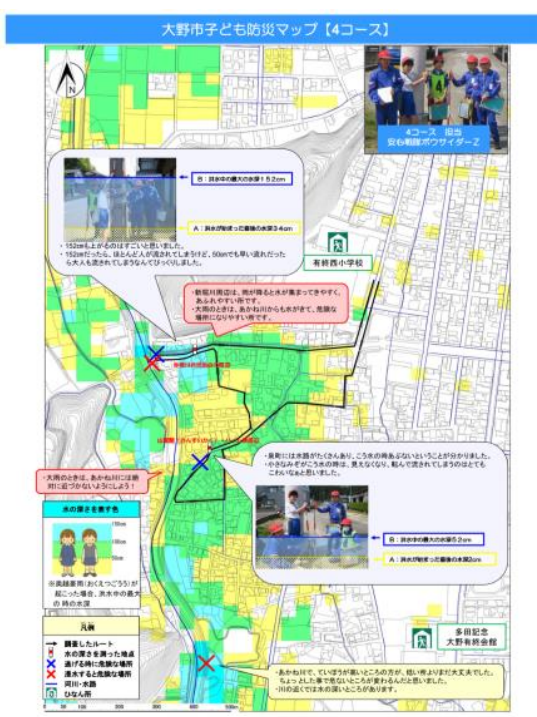

図-8＼cjkstart児童達が作成した地域の浸水リスクマップの例 
(2) アンケート結果から得られる防災教育の効果と浸 水リスクに対する意識の変化

対象児童に対して，地域の浸水リスクを伝える前と防 災教育を通じて地域の浸水リスクを身近な情報を通じて 確認した後で，災害に対するイメージがどのように変化 したか，「災害と言われて思いつくこと」という自由記 述のアンケート結果から確認した.

まず回答における災害の種別の結果を図-9 に示す. 対象である小学 5 年生にとっては, 大野市周辺において 被害をもたらした 2004 年の福井豪雨は経験しているも のの, 当時年齢が 1 歳前後であったことを考慮すると, 実際に災害に遭遇したという認識はほぼないと考えられ る。つまり，児童たちにとって災害はテレビなどを通じ て認識したものが多いと想定される．実際，図-9 に示 すように，事前調査における災害のイメージとして，比 較的身近に存在する大雨や汇濫などのリスク以上に，地 震や津波へのリスクの関心が高くなっている. 一方，事 後調査においては，地域の身近な災害リスクである水害 に対するリスクを挙げる生徒が大幅に増加している。 ま たそれと同時に 2011 年に発生した東日本大震災や火災, 事故，停電を除く，土砂災害や風，地震（一般）などの 他の災害についても言及寸る生徒が増えている点も特徴 である. この点は, 担任の先生からの意見として挙がっ た『日常の会話で「浸水深」という専門用語が聞かれる など，この学習のインパクトの強さを感じる．また，発 表の時の感想などを聞いていると，水害に対する考えが， はっきりと持てるようになっていた，水害だけでなく， その他の災害に関しても子供達は一人ひとり考える所が あったようだ. 少なくとも洪水が起きた時, 又起きそう な時に，赤根川に近づこうとする児童はこの学年では一 人もいないと思う。』という発言からも伺える事実であ る.ただし，当該地区は冬季に雪害の可能性がある地域
であるが，今回の防災教育では対象としなかった雪害に ついては災害のイメージが十分でない点も確認された。

本防災教育では大雨に関連するリスクを対象としてい るため，このような結果は当然とも言えるが，一方で， 児童達の災害に対するイメージ自体に大きな変化が確認 された。災害のイメージに対する回答表現の結果を表-4 に示す，事前調查では，圧倒的に「地震」や「台風」な どの単語のみによる表現が多く，災害に対する具体的な イメージを描写した児童は 5 名しかいなかった．しかし， 事後調査においては，具体的な災害時の状況を描写する 生徒の人数が 5 人から 22 人に増え, 谈害のイメージと して自分たちの地域のことを挙げる生徒が 1 名から 15 名に増えていた．また災害時の行動を挙げる生徒も 8 名 存在した. 平均文字数も 17.7 文字から 90.1 文字と 5 倍以 上になっていた，この結果は，テレビなどを通じて理解 していた他の地域における災害を，児童たちにとって災 害リスクを身近な情報として確認することを通して，災 害を自分自身のこととして認識するに至った効果と考え られる.

なお，授業後において，地域防災計画を理解したとい う生徒が 39 人中 37 人いた点も，地域防災計画を今後住 民の視点に落とし込む，才なわち防災の日常化を図る上 で，今回の検討は重要な結果であり，今後の洪水対策に おけるひとつの方向性を示したと考えられる.

\section{6. まとめ}

本研究では, 高解像内外水汇濫解析モデルを利用し, 大野市における奥越豪雨の事例を対象に，中小規模の河 川における想定災害リスクを評価するとともに，そこか ら地域にとって身近な災害情報の検討を行った，そして，

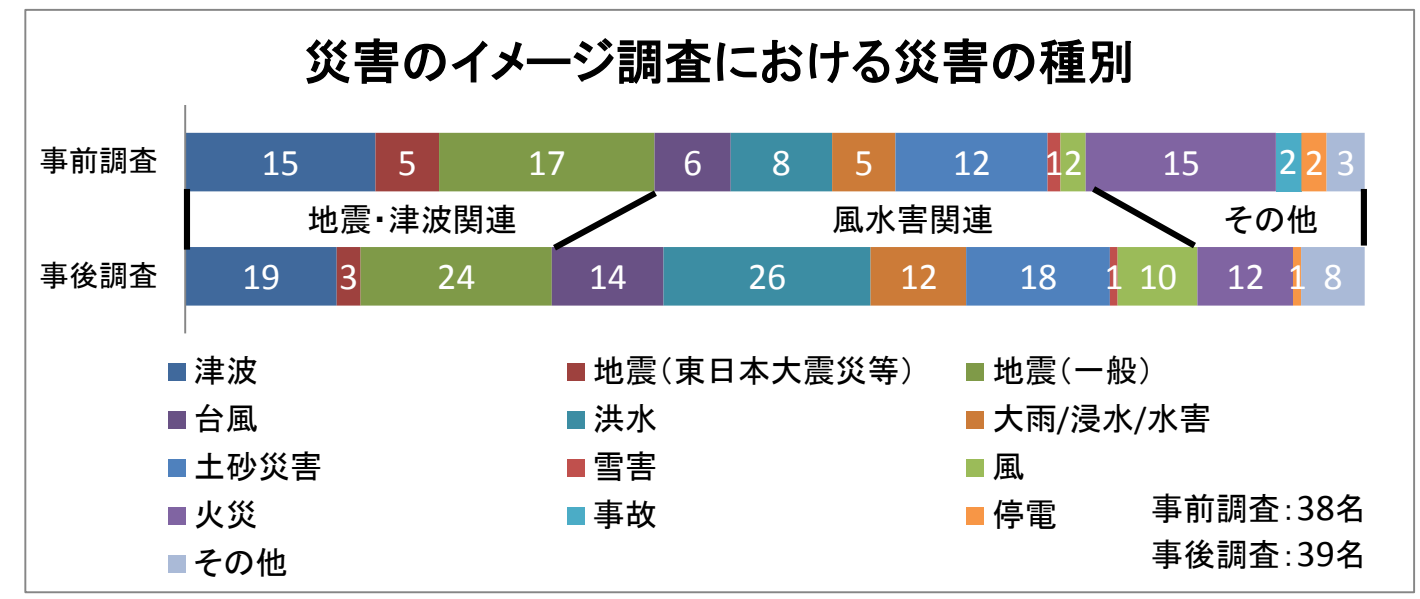

図-9 児童に対する災害のイメージ調査における災害の種類別の回答数

表-4 児童に対する災害のイメージ調査の回答における各表現内容の言及数と平均文字数

\begin{tabular}{cccccc}
\hline 表現内容等 & 回答数 & 災害の描写 & 災害時の行動 & 地域のこと & 平均文字数 \\
\hline 事前調查 & 38 & 5 & 0 & 1 & 17.7 文字 \\
\hline 事後調查 & 39 & 22 & 8 & 15 & 90.1 文字 \\
\hline
\end{tabular}


わかりやすく身近な情報として災害情報を提供する枠組 みの一つとして，地域気象情報の概念を導入し，汇濫解 析モデルと地域の災害情報の関係性について, 現行の気 象情報との関係性も含め評価した。その結果，汇濫解析 モデルを利用することで，事前に地域の浸水リスクを評 価し，そのリスク情報を従来から慣れ親しんだ気象情報 や他の災害情報と結びつけることで，今後起こりうる豪 雨被害に対して，事前に対応できる可能性を示寸ととも に，内外水汇濫に対する住民自らの避難判断の目安につ いて，地域の情報から設定できる可能性を示した.

またこの結果を基に，大野市立有終西小学校 5 年生 39 名を対象に，汇濫解析の結果を地域の身近な災害情報と して捉える実践型防災教育を実施し，災害に対するイメ ージの変化をアンケート調查を通じて確認した．その結 果, 多数の生徒が災害に対して具体的なイメージを持つ とともに，災害を自分たちの地域のこととして捉えると いう変化が確認され，事前に汇濫解析の結果を身近な情 報として確認し利用することの一つの有用性を示した.

今後，本取組を地域に広げるとともに，地域住民一の 調查を通じ，地域にとってより有効な地域気象情報の検 討を進めたい．また地域に身近な災害情報による災害対 応は，地区防災計画の具体化のためにも有効と考えられ ることから，この点についても検討を進めたい.

謝辞 : 本研究は, 大野市における新たな地域防災計画の 策定に向けた取組の一環として実施しています。ご協力 頂いている大野市役所の関係者の皆さま，大野市の住民 の皆さまには，この場を借りて切に感謝申し上げます.

\section{参考文献}

1) 気像庁: 洪水予報の発表形式の改善について, 報道発表資料, 国土交通省河川局・気象庁予報部，2007.

2) 田中信行，太田玩磨，牧原康隆 : 流域雨量指数による洪水警 報・注意報の改善，測候時報，75，35-69，2008.
3) 気象庁 : 気候変動監視レポート2012,平成25年6月,2013.

4) 宇治市: 平成24年8月13日14日京都府南部地域豪雨にかかる 災害対応及び災害復旧計画について,平成25年1月25日,2013.

5) 㴰健太郎，松田哲裕，鵜飼絵美，小笠原豊，西嶌照毅，中谷 惠剛：中小河川群の汇濫域における減災型治水システムの設 計，河川技術論文集，第16巻，pp.477-482，2010.

6) 田中耕司, 原田翔太, 岡田裕行, 瀧健太郎 : 中小河川群の汇 濫域における地区別避難判断基準の設定，土木学会論文集 B1(水工学), Vol.68, No.4, I_1087-I_1092, 2012.

7) 気象庁：「防災気象情報の利活用状況等に関する調査」の調 查結果について平成23年5月,2011.

8) 矢守克也：災害情報のダブル・バインド, 特集 災害情報リテ ラシー, 災害情報,Vol.7,pp.28-33,2009.

9) 淺田純作，片田敏孝，岡島大介，小葉竹重機 : 洪水避難に関 わる情報提供とその住民理解に関する研究，土木学会水工学 論文集，第45巻，pp.37-42,2001.

10) 竹之内健介, 島田真吾, 河田慈人, 中西千尋, 矢守克也 : 地 域気像情報の共有による減災の取組〜伊勢市辻久留地区にお けるアンケート調査を通じて〜，災害情報, No.11, pp.101-113, 2013.

11）内閣府(防災担当)：地区防災計画ガイドライン〜地域防災力 の向上と地域コミュニティの活性化に向けて〜, 平成26年3月, 2014.

12）高村弘毅, 河野忠 : 名水を訪ねて一大野盆地の湧水群一御清 水, 日本地下水学会誌, Vol.23, No.3, pp.255-261, 1994.

13）九頭竜川水系治水百周年記念事業実行委員会 : 九頭竜川流域 誌一水との戦いそして共生一,2000.

14) 福井県土木部 : 平成16年7月福井豪雨災害誌,2005.

15）中島秀明 - 田中耕司 - 中北英一 - 竹之内健介 - 矢守克也 - 養 老伸介・羽生雅則 : 中小河川群の氾濫リスクと避難判断・行 動の事前予測方法，河川技術論文集，第20巻，2014.

(2014.7.18 受付)

\title{
IMAGINATION OF DISASTER IN LOCAL DISASTER MANAGEMENT PLAN BY UTILIZING FLOOD INUNDATION ANALYSIS ON SMALL-MEDIUM RIVER AND WEATHER INFORMATION
}

\author{
Kensuke TAKENOUCHI, Hideaki NAKASHIMA, Kohji TANAKA, \\ Eiichi NAKAKITA, Katsuya YAMORI, Shinsuke YORO and Masanori HANYU
}

It is difficult to judge and forecast flood risk on small-medium rivers, because the risk is related to various local factors such as channel network and land use. In this research, high-resolution flood inundation analysis model was utilized to confirm details of flood risk and a result of the analysis is transformed to local disaster information which is familiar to inhabitants (Local weather information). An availability of this method is checked and its relations to weather information are evaluated. As an example, this research taked an event of the Okuetu heavy rainfall, which happened on September in 1965 around Oono City and caused heavy damages. The practical disaster education with the local disaster information based on the results of flood inundation analysis was provided to some students in Yushunishi elementary school in Oono and we have checked the effect from the pre/post questionary surveys. 